\title{
Time-varying market integration and stock and bond return concordance in emerging markets is
}

\author{
Valentyn Panchenko ${ }^{\mathrm{a}}$, Eliza $\mathrm{Wu}^{\mathrm{b}, *}$ \\ ${ }^{a}$ School of Economics, University of New South Wales, Sydney, NSW 2052, Australia \\ ${ }^{\mathrm{b}}$ School of Banking and Finance, University of New South Wales, Sydney, NSW 2052, Australia
}

\section{A R T I C L E I N F O}

\section{Article history:}

Received 20 July 2008

Accepted 30 October 2008

Available online 8 November 2008

\section{JEL classification:}

F36

G11

G15

Keywords:

Stock-bond comovement

Emerging market integration

Financial liberalization

Investibility

\begin{abstract}
A B S T R A C T
We investigate the extent to which emerging stock market integration affects the joint behavior of stock and bond returns using a two-stage semi-parametric approach. Using a sample of 18 emerging markets, we find an unambiguous and robust link between emerging stock market integration and stock-bond return decoupling. We explain this with a decline in the segmentation risk premia in equities modeled by De Jong and De Roon [De Jong, F., De Roon, F.A., 2005. Time-varying market integration and expected returns in emerging markets. Journal of Financial Economics 78, 583-613] that leads to increased demand for stocks and reduced or unchanged demand for bonds. Our findings deliver new insights into the financial liberalization and stock-bond comovement literatures.
\end{abstract}

(C) 2008 Elsevier B.V. All rights reserved.

\section{Introduction}

A major hallmark of financial development and reform is the experience of opening up emerging markets to foreign portfolio investment and the continuing reductions in barriers to foreign investment. Portfolio debt and equity flows to emerging markets are closely monitored by financial market participants and international policy makers alike. As such it is critical to understand the dynamic relationship between stock and bond returns in emerging financial markets. Yet, very little is known about their joint behavior in the face of their well-documented financial integration with world capital markets as restrictions on foreign ownership of assets have been gradually lifted post-financial liberalization.

Over the past decade, many academic studies have investigated the impacts of stock market liberalization and integration on the real economy (see for example, Bekaert and Harvey, 1995, 2000;

\footnotetext{
Wu wishes to acknowledge financial support from the Australian School of Business at the University of New South Wales for this project. Both authors would like to thank participants at the 6th INFINITI conference on international finance and seminar participants at the University of Wisconsin, Wayne State University, University of Queensland and University of Western Australia for helpful suggestions that improved earlier versions of this paper. All errors remain our own.

* Corresponding author. Tel.: +612 93855889; fax: +61293856347.

E-mail addresses: v.panchenko@unsw.edu.au (V. Panchenko), e.wu@unsw. edu.au (E. Wu).
}

Bekaert et al., 2005; Henry, 2000a,b). At the same time, there has also been much light shed in the literature on the effects of stock market integration on emerging countries' stock market characteristics (see inter alia Bae et al., 2004, 2006; Bekaert and Harvey, 1995, 1997, 2000, De La Torre et al., 2007; Kim and Singal, 2000; Patro and Wald, 2005) as well as its asset pricing implications (Carrieri et al., 2007; De Jong and De Roon, 2005). However, there has been a complete void on the effects of financial liberalization and stock market integration on cross-asset market relationships in emerging markets. Does the stock market opening experience impact on its relationship with the bond market as well? This question warrants attention given the importance of asset correlations for input into portfolio management and the increasing demand for emerging market assets by investors in developed countries seeking international diversification benefits and higher investment returns. Naturally, there are also important implications for financial system management by international policy makers.

To address this burgeoning gap in current knowledge, this study aims to examine the extent to which emerging stock market integration influences the joint behavior of stock and bond returns over time. This study is most closely related to the literatures on the impacts of financial liberalization and intra-market stock-bond return comovements. It contributes a totally new dimension to not only the extant literature on stock and bond comovements that has traditionally focused on developed financial markets, but also to 
the stand-alone and rapidly growing literature on the effects of financial market liberalization policies in emerging market economies in recent decades. As emerging stock markets become less segmented the pricing mechanics of domestic financial assets will naturally evolve so it is important to understand how this gradual process changes cross-asset comovements over time. However, the dynamic nature of joint stock-bond market behavior has perplexed researchers in financial economics for years and there have been many attempts to understand their fundamental relationship. Hence, this study makes a much needed contribution to the stock-bond comovement literature by not only documenting its recent behavior in emerging markets but also in providing a new level of understanding on the influence of stock market integration on this behavior over time.

In this study, we use a non-parametric realized concordancebased measure to examine stock-bond market comovements for 18 emerging markets in a post-liberalization period from 1995 to 2005. We then estimate a conditional random effects logistic panel regression model for these market comovements along with timevarying market integration and other relevant control variables. We find evidence that as emerging stock markets become gradually opened up to foreign investors, their stock-bond market returns begin to decouple, even after controlling for domestic and international influences in alternative model specifications. Our explanation for the decoupling is that as stock market integration proceeds, the reduction in the segmentation risk premia priced into emerging market stock returns by De Jong and De Roon (2005) leads to an increasing demand for equities that is independent of the demand for bonds. This is also internally consistent with the notions of improved risk sharing between foreign and domestic stock market investors and hence reductions in costs of equity capital and systematic risks to world market levels from stock market liberalization as documented by Chari and Henry (2004). Furthermore, stock-bond return decoupling may also be a manifestation of improvements in stock market liquidity and equity analyst coverage following stock market openings (Bae et al., 2006).

Overall, this paper provides innovative contributions across the topics of international investment portfolio choices, cross-asset market linkages and financial market integration by extending the current knowledge on emerging stock market opening experiences to the cross-asset market impacts of stock market integration. Our main contribution is in documenting the different facets in which stock market integration influences stock-bond comovements over time. Finally, we also contribute to the measurement of stock-bond comovement by adopting a non-parametric concordance measure that is less sensitive to structural changes and outliers than standard parametric frameworks. As such, it is much better suited for capturing emerging financial market behavior.

The remainder of this paper is organized as follows: Section 2 provides an overview of the literature. Sections 3 and 4 detail the data and methodology used. Results are then presented in Section 5 before conclusions are reached in Section 6 .

\section{Related literature}

This study is closely related to the currently separate literatures on the impacts of stock market liberalization (and ensuing market integration) and the comovement between stock and bond returns within the same country. Hence, we review these in turn:

\subsection{Financial liberalizations}

The process of financial market integration evolves slowly over time and may experience short-term reversals. To study the impacts of this process, existing studies have used two alternative approaches. First, studies like Bekaert and Harvey $(1995,2000)$ and Henry (2000a) have focused on official liberalization dates and/or estimated structural breaks on economic and financial indicators to examine pre- and post-liberalization effects on emerging stock markets and the real economy. Second, other studies have focused on the variations in investibility for foreign investors [also termed 'the intensity of capital controls' by Edison and Warnock (2003)]. Specifically, the measure is based on the changing share of the equity market that is legally available to foreign investors relative to total market capitalization over time.

Existing academic studies have documented that opening financial markets to foreign investors enables risk sharing for domestic investors with foreign agents and this helps to lower the cost of capital and increases aggregate investment levels (Bekaert and Harvey, 2000; Chari and Henry, 2004 and Henry, 2000a,b. Other empirical studies on financial liberalization point to a wider range of immediate positive impacts being triggered by financial liberalization: declining expected stock returns and stock market volatilities; increased correlations and betas relative to world markets; increased real economic growth and improved information and corporate governance environments (via information production and disclosure and reduction in agency costs) (see Bae et al., 2004, 2006; Bekaert and Harvey, 1997, 2000; Bekaert et al., 2005; De Jong and De Roon, 2005; Edison and Warnock, 2003; Kim and Singal, 2000; Henry, 2000a,b).

Specifically in the asset pricing domain, the models of Bekaert and Harvey (1995), Carrieri et al. (2007) and De Jong and De Roon (2005) provide insightful views on the integration/segmentation paradigm of emerging markets as they transition from being segmented to fully integrated with world capital markets. International asset pricing models (IAPM) provide estimated return-based measures of market integration with implicit assumptions on what kind of risks are priced into emerging markets. The established framework in Bekaert and Harvey (1995) assumes that the variance of a market's return dominates in a segmented state whilst the covariance with world market returns then becomes relevant in an integrated state (and emerging markets will transition between the two polar specifications over time). In extending from this basic idea to a partial integration/segmentation IAPM, Carrieri et al. (2007) also introduce an integration index based on the variance ratios of a market portfolio of eligible stocks to the total country stock market (portfolio) index. Furthermore, in their generalized world CAPM, De Jong and De Roon (2005) consider a segmentation risk premia to be priced into emerging stock market expected returns and they allow world market betas to vary with market segmentation. The additional risk premia is caused by the hedging demands of investors for holding non-investible assets. They show that as emerging stock markets open up and integrate (become less segmented), this risk premia subsides thereby lowering the cost of capital (expected stock market returns). However, what remains to be addressed is whether this impacts on the stock markets' relationship to other asset markets.

\subsection{Stock-bond comovements}

The existing stock-bond literature is broadly in agreement on how stock and bond returns comove over time but not why stock and bond returns are jointly moving together. To date, what determines the time variation in stock-bond comovement remains an empirical puzzle. Early studies to understand the joint stock-bond relation can be represented by the present value model of Campbell and Ammer (1993) as they implicitly assume time-invariance in the stock-bond relation, and they find that observed levels cannot be justified by economic fundamentals. Since then, researchers have modeled the time-varying risk premia in their investigation 
and established that stock and government bond returns exhibit a modest positive correlation over a long horizon but the relationship is a dynamic one, suggesting that the amount of portfolio diversification with a given asset allocation is constantly changing (see inter alia Connolly et al., 2005; Fleming et al., 1998). In particular, Cappiello et al. (2006) and Scruggs and Glabadanidis (2003) investigate the asymmetric nature of stock and bond market conditional variances and their comovement in developed markets.

Surprisingly, for emerging financial markets, Kelly et al. (1998) is one of the few studies to focus on the relationship between stock and bond returns and they reveal that there are greater degrees of comovement in emerging markets than in mature financial markets because country risk in emerging economies makes domestic bond returns more 'equity like'. This pattern in intra-market stockbond correlations is reinforced byErb et al. (1999) in using institutional investor ratings. More recently, Li and Zou (2008) have also captured the asymmetric responses in stock-bond correlations to recent government policy decisions in China. In addition, Boyer et al. (2006) briefly examine correlations between stock and government bond returns during financial crises as part of their broader study on how crises spread. They show that financial crises spread through investible stocks in emerging markets.

In the studies based on informational linkages across asset returns (see Fleming et al. (1998) and Chordia et al. (2005)), a shock in one asset market will generate cross-market asset rebalancing and hence, volatility linkages. Government bonds are deemed to be a safe haven for investors engaging in a "flight to quality" in times of financial turmoil. As investors substitute safer assets for their risky ones, bond and stock market returns become negatively correlated with opposing price pressures exerted from increasing demand for bonds and declining demand for stocks (see Chordia et al., 2005; Connolly et al., 2005). More recently, stock market uncertainty has been provided by Connolly et al. (2005) and Kim et al. (2006) as a key explanation for the stock-bond return relation. They use implied volatilities from equity index options to reflect stock market uncertainty, emphasizing that this should be positively related to economic-state uncertainty. In spite of existing works, the explanation for time-varying stock-bond comovements remains unsatisfactory.

\section{Data}

For our empirical analyses, we obtained from Thomson Datastream a panel dataset of weekly local currency denominated Morgan Stanley Capital International (MSCI) and J.P. Morgan emerging bond market index total returns for stock and bond markets respectively from 18 emerging countries. The emerging markets studied are from various regions around the world -5 from Latin America (Argentina, Brazil, Mexico, Peru, Venezuela), 4 from the Middle East and Africa (Egypt, Israel, South Africa, Turkey), 5 from Asia (China, India, Indonesia, Philippines, Thailand) and 4 from Emerging Europe (Czech Republic, Greece, Poland, Slovak Republic). The sample period studied extends from January 1995 to December 2005. Our coverage in time and across countries was limited by the availability of all data required.

We also collected weekly country-level investible and global indices from Standard \& Poor's (previously International Finance Corporation's) Emerging Markets Database (EMDB). ${ }^{1}$ This database provides for each sample country the global and investible indices that represent the equity that is available in aggregate to all investors and to foreign investors respectively. We compute the specific

1 This database has also been used by Bae et al. (2004, 2006), Boyer et al. (2006), Carrieri et al. (2007), De Jong and De Roon (2005) and Edison and Warnock (2003) amongst others, to construct measures of investibility (to proxy for stock market integration or financial openness). country-level measure of 'investibility openness' based on the ratio of the market capitalization in these two indexes following Edison and Warnock (2003) and De Jong and De Roon (2005). This measure essentially captures the intensity of capital controls. It varies over time for individual countries as the foreign ownership limits and other controls on foreign investment are slowly removed with legal and regulatory changes.

In addition, as shown in Table 1 we also sourced data for control variables at the annual frequency (inflation, dividend yields, real, nominal and US short-term interest rates, MSCI world stock market index, stock market capitalization and turnover, debt outstanding, value of imports, exports, portfolio flows and GDP) from Datastream, the World Bank's World Development Indicators, the US Treasury Department's International Capital System (TIC) and the IMF's World Economic Outlook database. Sovereign credit ratings and outlook data on long-term foreign currency denominated debt was obtained from Standard and Poors and then transformed into a linear comprehensive country ratings measure following Ferreira and Gama (2007). ${ }^{2}$

\section{Methodology}

We follow a two-stage semi-parametric procedure for examining stock-bond concordance in emerging markets. Hence, we first discuss our non-parametric approach to measuring joint stock and bond return movements before outlining our regression framework used for empirical analyses.

\subsection{Measuring stock and bond comovement}

We first adopt a non-parametric measure between realized stock and bond returns to examine their joint movement. At each particular point of time the return comovement is considered to be concordant when realized returns $R$ of stocks and bonds are deviating from their averages AveR in the same direction. The comovement is considered discordant when return deviations from the corresponding averages have different signs. We define an indicator variable $C_{t}$ which takes the value of one in the case of concordant comovement, and zero in the case of discordant comovement at time $t$

$C_{t}=1$ if $\left(R_{\text {bond }, t}-A v e R_{\text {bond }}\right)\left(R_{\text {stock }, t}-A v e R_{\text {stock }}\right) \geq 0$,

$C_{t}=0$ if $\left(R_{\text {bond }, t}-A v e R_{\text {bond }}\right)\left(R_{\text {stock }, t}-A v e R_{\text {stock }}\right)<0$.

With the concordance indicator variable averaged over all observations we may estimate an unconditional probability of concordant movement. Furthermore, we use the logit specification to model the conditional probability of concordance and to determine factors that influence this conditional probability. Our measure for joint stock-bond comovement is closely related to rank correlation measures, such as Spearman's $\rho$ (Spearman, 1904) and Kendall's $\tau$ (Kendall, 1938). For the case of a bivariate normal distribution, there is a direct relationship between alternative rank correlation measures and Pearson's correlation coefficient that is commonly used in finance. We derive a one-to-one relationship between our concordance measure and Pearson's correlation coefficient (see Appendix). It is important to point out that our non-parametric measure is capable of detecting more general dependence patterns than the parametric Pearson's correlation coefficient that

\footnotetext{
${ }^{2}$ Numerical values were first assigned for each of the rating grades ranging from 0 for default/selective default to 20 for AAA rated sovereign obligors and then fractional adjustments were made for the credit outlook that varies from Credit Watch Positive to Credit Watch - Negative. The composite values were then assigned to sample countries on and after the day of announcement until subsequent revisions were made. Average ratings were then computed for each year for the panel regression analyses.
} 
Table 1

Description of variables. This table reports the categories, names and data sources for variables used in this study.

\begin{tabular}{|c|c|c|}
\hline Variable category & Variable & Data source \\
\hline \multirow[t]{2}{*}{ Dependent variable (constructed from) } & Weekly MSCI stock market returns & Datastream \\
\hline & Weekly JP Morgan ELMI Bond Returns & Datastream \\
\hline Independent variables: & Stock market integration (investibility) & Standard and Poor's Emerging Market Database \\
\hline \multirow[t]{6}{*}{ Country-specific } & Inflation (\%) & IMF's World Economic Outlook, World Development Indicators \\
\hline & Real interest rate, nominal interest rate (\%) & World Development Indicators \\
\hline & Dividend yield, $\mathrm{P} / \mathrm{E}$ ratio (\%) & World Federation of Stock Exchanges, Datastream \\
\hline & Quality yield spread over US (\%) & Datastream \\
\hline & Sovereign credit ratings & Standard and Poor's \\
\hline & Economic Freedom Index & The Heritage Foundation http://www.heritage.org/index \\
\hline \multirow[t]{3}{*}{ International } & US short-term interest rates $(\%)$ & Datastream \\
\hline & MSCI world stock market volatility & Datastream \\
\hline & VIX implied volatility S\&P500 & Datastream \\
\hline \multirow[t]{4}{*}{ Market-development } & Market capitalization of listed companies (\%GDP) & World Development Indicators \\
\hline & Stocks traded, turnover ratio (\%) & World Development Indicators \\
\hline & Total value of stocks traded (\%GDP) & World Development Indicators \\
\hline & Amt short-term debt/total external debt (\%) & World Development Indicators \\
\hline \multirow[t]{4}{*}{ Financial openness } & Total portfolio flows from US (\% GDP) & TIC, US Treasury http://www.treas.gov/tic/ \\
\hline & Gross capital flows (\% GDP) & World Development Indicators \\
\hline & Trade openness (\%) (imports + exports/GDP) & World Development Indicators \\
\hline & Financial openness & Chinn and Ito (2006) http://www.ssc.wisc.edu/ mchinn/ \\
\hline
\end{tabular}

strongly relies on the assumption of elliptical symmetry (normality). Non-parametric measures are robust towards outliers and structural changes whereas the Pearson's correlation coefficient can be strongly affected by both (for details see Embrechts et al., 1999).

The major advantage of the adopted non-parametric concordance measure over commonly used variants of multivariate GARCH and regime-switching model estimates used in the extant stock-bond comovement literature is that our measure does not require the imposition of any formal parametric model on stock and bond returns to create an empirical proxy for the true conditional stock-bond correlation. While GARCH and regime-switching models provide good approximation of returns evolution for developed markets, these structures are not as suitable for modeling emerging market returns due to limited time series data availability and frequent structural breaks observed (see Bekaert and Harvey, 1997 and references therein).

\subsection{Testing the effects of stock market integration}

To empirically assess whether the variability in stock market investibility levels across emerging markets impact on the timevariations in stock and bond market concordance, we estimate logit regressions for the conditional probability of concordance. The logit regressions are estimated for the panel of 18 emerging market countries using weekly concordance and market integration data over the 1995-2005 period. Due to the limited availability of macroeconomic data at higher frequencies, we have employed annual macroeconomic control variables consistent with treatment in other studies like Kim et al. (2006). ${ }^{3}$

This framework allows us to make maximum use of information available to study variations in the relation between stock and bond returns over a cross-section of countries and over time. We use the Hausman test to determine whether fixed effects or random effects specification is appropriate. For most model specifications used in this paper, the Hausman test indicates the selection of the random effects model against the alternative of the fixed effects model.

\footnotetext{
${ }^{3}$ By employing the annual macroeconomic control variables we reduce their time variation within higher frequency. However, their higher frequency variation is relatively small and practically does not influence the results of the regression. The results are mostly driven by the cross-sectional variation in the control variables between different countries (that is almost fully preserved when we use annual frequency control variables).
}

In the spirit of De Jong and De Roon (2005) and Edison and Warnock (2003) the continuous measure of market integration (with the world, $I_{i t}$ ) for each sample country $i$ is defined as the market value of the investable assets that can be legally held by foreign investors at time $t\left(V_{i t}\right)$ as a proportion of the total invested wealth by domestic and international investors in the overall emerging market portfolio $\left(G_{i t}\right)$. This is computed as the total market capitalization of the S\&P Investable Index over the S\&P Global Index for each country. By construction a ratio of 1 means that all of a country's issued shares are legally acquirable by foreign investors. The ratio is bounded between 0 and 1 . This is the main independent variable of interest and can be represented as

$I_{i t}=\frac{V_{i t}}{G_{i t}}$.

It should be noted that our research methodology was designed with the potential market frictions within emerging markets in mind. As information dissemination and market transactions may be slower within emerging markets, we opt to use weekly returns to measure stock and bond concordance measures for our regression analyses. We also control for time evolution (in unobserved characteristics) using a trend variable and to further control for the possibility of a spurious relationship between our market integration and stock-bond concordance series. However, the trend variable is insignificant in all model specifications.

To mitigate the problems of omitted variable bias and to take into account the existing empirical stock-bond comovement literature, we also add control variables like proxies for economic state uncertainty (Connolly etal., 2005; Kim et al., 2006), macroeconomic fundamentals (Campbell and Ammer, 1993; Scruggs and Glabadanidis, 2003), alternative economic and financial openness measures (Bekaert and Harvey, 2000; Bae et al., 2006; Chinn and Ito, 2006) and country ratings (Kelly et al., 1998; Erb et al., 1999) to ascertain the additional explanatory power of stock market integration and to check for robustness in its empirical relationship with stock-bond concordance in emerging markets. ${ }^{4}$

We estimate the conditional probability of stock and bond return concordance using the logistic panel regression model with country specific (fixed or random) effects shown below:

\footnotetext{
${ }^{4}$ Due to space limitations, we do not report estimates for all control variables and the time trend but full sets of estimation results are available upon request.
} 


$$
P\left(C_{i t}=1\right)=\frac{1}{1+\exp \left[-\left(\alpha+\theta I_{i t}+\beta X_{i t}+u_{i}\right)\right]},
$$

where $P$ is a probability measure, $C_{i t}$ is the indicator variable taking the value of one when the stock and bond price movements are concordant and zero when they are discordant, $I_{i t}$ is the stock market integration variable defined above, $X_{i t}$ is a vector of control variables and $u_{i}$ is a country specific component.

To facilitate interpretation of the coefficient estimates, it is useful to rewrite the logistic model in Eq. (3) in terms of the logarithm of the odds ratio that stock and bond markets are concordant, that is

$\ln \left(P\left(C_{i t}=1\right) / P\left(C_{i t}=0\right)\right)=\alpha+\theta I_{i t}+\beta X_{i t}+u_{i}$.

The coefficient estimates can now be interpreted as linear marginal effects on the logarithm of the odds ratio. The model is estimated using a maximum likelihood estimator assuming a normal distribution for the random country specific component.

\section{Empirical results}

We discuss our empirical results in two different respects. First we present and interpret the results from our logistic panel regression on domestic and international levels. Secondly, we assess the incremental effects of market integration over alternative financial and economic openness measures as a robustness check on our primary findings.

\subsection{Panel regression results}

\subsubsection{Market integration and country-specific influences}

Table 2 reports estimates of the coefficients for six alternative specifications of the conditional logistic panel regression. We find that the market integration variable is consistently negative and statistically significant at the $5 \%$ and $10 \%$ levels for explaining the probability of stock-bond return concordance in nearly all instances. ${ }^{5}$ Thus, as stock market integration increases in emerging market countries the likelihood of concordance (discordance) across stock and bond returns decreases (increases). However, the effects are temporary as a lag of the dependent variable was found to be insignificant indicating that there is no persistence in the relationship. ${ }^{6}$

This can be explained by a reduction in the segmentation risk premia in equity returns established by De Jong and De Roon (2005). When an emerging stock market is segmented from the rest of the world (non-investible), there is a high segmentation risk premia priced into the emerging market's stocks. However, as the stock markets open up, the segmentation risk premia (and hence equity risk premia) is reduced as greater risk sharing between foreign and domestic equity investors is enabled. The inverse relationship suggests that increased demand for equities must lead to different price pressures in the country's stock and bond markets. This can be caused by progressively increased demand for equities and either unchanged or reduced demand for bonds.

The control variables included in alternative model specifications (1)-(6) in Table 2 are based on the existing stock-bond comovement literature. Most importantly, we incorporate the main fundamental variables established in the stock-bond literature

5 To shed further light on the relationship between market integration and stockbond relationship, we also investigated the concordance in realized stock and bond variances but results were insignificant and have been omitted for brevity. As the probabilities of the concordance in realized stock and bond variances were close to 0.5 , we are confident that our return results are not influenced by heteroskedastic biases.

${ }^{6}$ Regressions with higher lags of the dependent variable yielded the same conclusion. These estimates are available upon request. by Campbell and Ammer (1993) and Scruggs and Glabadanidis (2003) amongst others - namely, inflation, dividend yields, credit quality spreads and nominal and real short-term interest rates. ${ }^{7}$ Contrary to studies based on US treasury bond and stock markets, we find in emerging markets (where inflation is more pronounced) that inflation has a highly significant and positive influence on the stock-bond relationship. Inflationary pressures impact on both stock and bond prices through the discounting of cashflow framework resulting in increased stock-bond concordance. Dividend yields are not significant but the negative signs suggest that they work to increase the prices of stocks but not bonds consistent with the Campbell and Ammer (1993) framework. The country's credit quality spread over the US signals the perceived riskiness and relative cost of funds and is significant and positively related to stock and bond return concordance. Interestingly, we find that the country's own short-term interest rates (both nominal and real) are not significant fundamental determinants as it appears that only the relative borrowing costs are of concern to stock and bond market investors in developing economies.

It is well accepted in the existing literature that financial market development is closely related to financial market integration (Bekaert and Harvey, 2000; Bekaert et al., 2005; Carrieri et al., 2007). We find that stock market development measures (as proxied by stock market capitalization to GDP, stocks traded and stock market turnover) have significantly negative effects on cross-asset market comovements within emerging markets, consistent with the impacts of the stock market integration variable discussed above. Institutional quality as captured by country ratings and the Economic Freedom Index do not have additional impacts on the same country stock-bond relation. ${ }^{8}$

\subsubsection{Market integration and international economic influences}

We present evidence in Table 3 that the underlying significantly inverse relationship between stock market integration and the odds of joint stock and bond return behavior holds up to international influences on emerging financial markets. Given the established influence of economic uncertainty on stock-bond comovements in Connolly et al. (2005) and Kim et al. (2006) and the fact that asset returns are known to increase during volatile periods, we use alternative proxies to capture the potential effects of global economic uncertainties on the stock-bond relationship within emerging markets. The estimated coefficients for the US short term interest rate, the well-known S\&P 500 implied volatility index (VIX) and MSCI world stock market volatility, are all shown in Table 3. ${ }^{9}$ Of these external influences on stock-bond relations in emerging markets only US interest rates are significant. The positive coefficient suggests that both emerging stock and bond markets are affected by changing global costs of capital.

Domestic inflation and stock market development continues to be significant control variables and have the same signs as previously discussed. Importantly, the stock market integration variable remains significantly negative indicating that it provides additional explanatory power over both domestic and international influences on the emerging market stock-bond relation.

\footnotetext{
${ }^{7}$ The term structure is another fundamental variable featured in existing US stockbond comovement studies but it is not as relevant for emerging markets as most do not have sufficiently well developed bond markets at the long-term end.

${ }^{8}$ In preliminary correlation analyses, we find that the stock market and institutional development measures are indeed highly correlated. As such, we do not find incremental explanatory power for country ratings.

${ }^{9}$ We also considered the volatility of emerging markets' real exchange rates with the US dollar as another international factor but this was insignificant. This is not surprising given that we are examining concordance between local currency stock and bond returns, i.e. purely domestic cross-asset market comovements free of currency risks.
} 
Table 2

Effects of market integration and domestic influences on stock-bond concordance. This table reports the estimated results from the logit regressions given by Eq. (4) for six alternative model specifications shown with market integration, and different sets of country-specific explanatory variables. The dependent variable is the log odds ratio of stockbond concordance in all cases. $P$-values are shown in parentheses. Regression diagnostics: Log Likelihood at the maximum, Wald test for joint significance of all parameters.

\begin{tabular}{|c|c|c|c|c|c|c|}
\hline & 1 & 2 & 3 & 4 & 5 & 6 \\
\hline Lag 1 concordance & $\begin{array}{r}-0.0407 \\
(0.452)\end{array}$ & & & & & \\
\hline Mkt integration & $\begin{array}{r}-0.2260 \\
(0.099)\end{array}$ & $\begin{array}{r}-0.2213 \\
(0.100)\end{array}$ & $\begin{array}{c}-0.2398 \\
(0.076)\end{array}$ & $\begin{array}{r}-0.2518 \\
(0.026)\end{array}$ & $\begin{array}{c}-0.1940 \\
(0.057)\end{array}$ & $\begin{array}{r}-0.2310 \\
(0.029)\end{array}$ \\
\hline Inflation & $\begin{array}{r}-0.5327 \\
(0.276)\end{array}$ & $\begin{array}{r}-0.4857 \\
(0.319)\end{array}$ & $\begin{array}{c}-0.4456 \\
(0.359)\end{array}$ & $\begin{array}{r}0.2033 \\
(0.417)\end{array}$ & $\begin{array}{r}0.4863 \\
(0.001)\end{array}$ & \\
\hline Dividend yield & $\begin{array}{r}-2.0646 \\
(0.217)\end{array}$ & $\begin{array}{r}-2.0533 \\
(0.219)\end{array}$ & $\begin{array}{c}-1.7386 \\
(0.289)\end{array}$ & & & \\
\hline Quality spread over US interest rate & $\begin{array}{r}0.9951 \\
(0.072)\end{array}$ & $\begin{array}{r}0.9461 \\
(0.087)\end{array}$ & $\begin{array}{c}0.9534 \\
(0.084)\end{array}$ & $\begin{array}{r}0.4666 \\
(0.154)\end{array}$ & & $\begin{array}{r}0.6301 \\
(0.001)\end{array}$ \\
\hline Market capitalization (share of GDP) & $\begin{array}{r}-0.2603 \\
(0.001)\end{array}$ & $\begin{array}{r}-0.2506 \\
(0.001)\end{array}$ & $\begin{array}{c}-0.2346 \\
(0.002)\end{array}$ & $\begin{array}{r}-0.1631 \\
(0.014)\end{array}$ & $\begin{array}{c}-0.1198 \\
(0.044)\end{array}$ & $\begin{array}{r}-0.1367 \\
(0.021)\end{array}$ \\
\hline Stocks traded, turnover ratio & $\begin{array}{r}-0.1071 \\
(0.137)\end{array}$ & $\begin{array}{r}-0.1032 \\
(0.151)\end{array}$ & $\begin{array}{r}-0.1107 \\
(0.122)\end{array}$ & $\begin{array}{r}-0.1157 \\
(0.039)\end{array}$ & $\begin{array}{r}-0.0636 \\
(0.201)\end{array}$ & $\begin{array}{r}-0.0921 \\
(0.081)\end{array}$ \\
\hline Short-term debt (share of total external debt) & $\begin{array}{r}0.6870 \\
(0.033)\end{array}$ & $\begin{array}{c}0.6564 \\
(0.041)\end{array}$ & $\begin{array}{r}0.6911 \\
(0.031)\end{array}$ & $\begin{array}{c}0.1494 \\
(0.524)\end{array}$ & & \\
\hline Country rating & $\begin{array}{c}-0.0134 \\
(0.352)\end{array}$ & $\begin{array}{r}-0.0129 \\
(0.370)\end{array}$ & $\begin{array}{r}-0.0145 \\
(0.311)\end{array}$ & & & \\
\hline Economic Freedom Index & $\begin{array}{r}-0.0012 \\
(0.350)\end{array}$ & $\begin{array}{r}-0.0012 \\
(0.327)\end{array}$ & & & & \\
\hline Log likelihood & -3862 & -3870 & -3871 & -4809 & -5311 & -5310 \\
\hline Wald test & 0.0149 & 0.0125 & 0.0101 & 0.001 & 0.0006 & 0.0005 \\
\hline
\end{tabular}

\section{Table 3}

Effects of market integration and major domestic and international influences on stock-bond concordance. This table reports the estimated results from the logit regressions given by Eq. (4) for five alternative model specifications with market integration, major domestic variables and different sets of international variables capturing the state of the global economy and a time trend. The dependent variable is the log odds ratio of stock-bond concordance in all specifications. $P$-values are shown in parentheses. Regression diagnostics: Log Likelihood at the maximum, Wald test for joint significance of all parameters.

\begin{tabular}{|c|c|c|c|c|c|}
\hline & 1 & 2 & 3 & 4 & 5 \\
\hline Mkt integration & $\begin{array}{l}-0.1557 \\
(0.130)\end{array}$ & $\begin{array}{l}-0.1596 \\
(0.121)\end{array}$ & $\begin{array}{l}-0.1613 \\
(0.116)\end{array}$ & $\begin{array}{l}-0.1933 \\
(0.058)\end{array}$ & $\begin{array}{l}-0.1836 \\
(0.073)\end{array}$ \\
\hline Inflation & 0.0040 & 0.0039 & 0.0040 & 0.0048 & 0.0046 \\
\hline Market capitalization (share of GDP) & $\begin{array}{l}-0.0012 \\
(0.047)\end{array}$ & $\begin{array}{l}-0.0012 \\
(0.050)\end{array}$ & $\begin{array}{l}-0.0012 \\
(0.053)\end{array}$ & $\begin{array}{l}-0.0012 \\
(0.044)\end{array}$ & $\begin{array}{l}-0.0013 \\
(0.033)\end{array}$ \\
\hline Stocks traded, turnover ratio & $\begin{array}{l}-0.0005 \\
(0.282)\end{array}$ & $\begin{array}{l}-0.0005 \\
(0.284)\end{array}$ & $\begin{array}{l}-0.0006 \\
(0.268)\end{array}$ & $\begin{array}{l}-0.0006 \\
(0.207)\end{array}$ & $\begin{array}{l}-0.0006 \\
(0.246)\end{array}$ \\
\hline US interest rate & $\begin{array}{l}0.0287 \\
(0.061)\end{array}$ & $\begin{array}{l}0.0379 \\
(0.005)\end{array}$ & $\begin{array}{l}0.0375 \\
(0.005)\end{array}$ & & \\
\hline VIX & $\begin{array}{l}0.0117 \\
(0.341)\end{array}$ & $\begin{array}{l}-0.0020 \\
(0.716)\end{array}$ & & $\begin{array}{l}-0.0009 \\
(0.873)\end{array}$ & \\
\hline World stock market volatility $(\times 1000)$ & $\begin{array}{l}-1.5287 \\
(0.212)\end{array}$ & & & & $\begin{array}{l}-0.7398 \\
(0.171)\end{array}$ \\
\hline Log likelihood & -5306 & -5307 & -5306 & -5311 & -5309 \\
\hline Wald test & 0.0001 & 0.0001 & 0.0000 & 0.015 & 0.0007 \\
\hline
\end{tabular}

Table 4

Incremental effects of market integration on stock-bond concordance. This table reports the estimated results from the logit regressions given by Eq. (4) for five alternative model specifications with market integration, major domestic variables and different sets of additional openness variables. The dependent variable is stock-bond concordance in all specifications. $P$-values are shown in parentheses. Regression diagnostics: Log Likelihood at the maximum, Wald test for joint significance of all parameters.

\begin{tabular}{|c|c|c|c|c|c|}
\hline & 1 & 2 & 3 & 4 & 5 \\
\hline Mkt integration & $\begin{array}{l}-0.4586 \\
(0.028)\end{array}$ & $\begin{array}{l}-0.1849 \\
(0.227)\end{array}$ & $\begin{array}{l}-0.2099 \\
(0.041)\end{array}$ & $\begin{array}{l}-0.1886 \\
(0.064)\end{array}$ & $\begin{array}{l}-0.2008 \\
(0.063)\end{array}$ \\
\hline Inflation & $\begin{array}{l}0.2533 \\
(0.274)\end{array}$ & $\begin{array}{l}0.3310 \\
(0.141)\end{array}$ & $\begin{array}{l}0.4788 \\
(0.001)\end{array}$ & $\begin{array}{l}0.4217 \\
(0.004)\end{array}$ & $\begin{array}{l}0.4910 \\
(0.001)\end{array}$ \\
\hline Market capitalization (share of GDP) & $\begin{array}{l}-0.1775 \\
(0.037)\end{array}$ & $\begin{array}{l}-0.1667 \\
(0.016)\end{array}$ & $\begin{array}{l}-0.1272 \\
(0.033)\end{array}$ & $\begin{array}{l}-0.1494 \\
(0.015)\end{array}$ & $\begin{array}{l}-0.1009 \\
(0.119)\end{array}$ \\
\hline Stocks traded, turnover ratio & $\begin{array}{l}0.1263 \\
(0.273)\end{array}$ & $\begin{array}{l}-0.0587 \\
(0.948)\end{array}$ & $\begin{array}{l}-0.0629 \\
(0.206)\end{array}$ & $\begin{array}{l}-0.0401 \\
(0.433)\end{array}$ & $\begin{array}{l}-0.0144 \\
(0.794)\end{array}$ \\
\hline Gross private capital flows (share GDP) & $\begin{array}{l}0.9641 \\
(0.128)\end{array}$ & $\begin{array}{l}0.2330 \\
(0.657)\end{array}$ & & & \\
\hline Trade openness (import + exports, share of GDP) & $\begin{array}{l}-0.2333 \\
(0.096)\end{array}$ & & $\begin{array}{l}-0.1201 \\
(0.107)\end{array}$ & & \\
\hline US portfolio flows (share of GDP) & $\begin{array}{l}1.5512 \\
(0.095)\end{array}$ & & & $\begin{array}{l}1.2043 \\
(0.052)\end{array}$ & \\
\hline Financial openness measure & $\begin{array}{l}0.0254 \\
(0.524)\end{array}$ & & & & $\begin{array}{l}0.0317 \\
(0.137)\end{array}$ \\
\hline Log likelihood & -2739 & -2830 & -5309 & -5309 & -5096 \\
\hline Wald test & 0.0228 & 0.0235 & 0.0005 & 0.0003 & 0.0007 \\
\hline
\end{tabular}


5.1.3. Robustness check: alternative openness proxies

To the extent that stock market investibility simply proxies the level of economic or financial openness over time, we check the incremental explanatory power of our stock market integration measure based on investibility in emerging stock markets with alternative financial openness measures commonly used in the international portfolio flow literature. These include gross private capital flows as a percentage of GDP, trade openness measured by the total value of imports and exports as a percentage of GDP, total portfolio flows to and from the US and Chinn and Ito's (2006) financial openness measure. The latter measure captures capital account openness based on four binary indicators for components of capital controls in the IMF's Annual Report on Exchange Arrangements and Exchange Restrictions (AREAER). As expected these proxies broadly work to encourage the odds of stock-bond concordance as openness leads to increasing demand for financial assets.

Of all proxies, we find financial flows to be particularly important. We employ total portfolio flows between the US and each of our sample countries using the US treasury's TIC data. Whilst this is clearly not a good measure of market integration from an asset pricing perspective, it does capture a significant proportion of the capital movements into and out of emerging markets and importantly, for understanding the channels of stock-bond comovements in emerging markets. The estimated coefficient is economically and statistically significant at the $10 \%$ level. Consistent with Bae et al. (2006), we find that stock market investibility remains significant in the presence of US portfolio flow measures (see Table 4).

In sum, we find that the basic inverse and significant relationship between increasing stock market integration and the probability of stock-bond concordance remains after controlling for alternative measures of financial and economic openness. This suggests that market investibility is a good measure for market integration as it has strong incremental explanatory power on joint stock-bond behavior over other measures. As emerging stock markets become more open to and integrated with the rest of the world, their domestic stock and bond returns are likely to become significantly more discordant, from differential demand pressures on stocks and bonds as the segmentation risk premia declines in stocks. This suggests that efforts to open up emerging stock markets provide investors with greater diversification opportunities over time.

\section{Conclusions}

This paper employs a semi-parametric approach to study the impact of market integration on an emerging market's stock-bond relationship. We find evidence of a robust inverse relationship suggesting that stock market openings lead to an increase in demand for equities as the segmentation risk premia is reduced and also an either unchanged or reduced demand for bonds.

Our results suggest that in the process of opening up relatively small and undeveloped stock markets in emerging economies, foreign equity investments work to increase diversification opportunities across emerging security markets. The basic result is robust to alternative model specifications with controls for country-specific fundamentals, global economic uncertainties and financial and economic openness.

Overall, we deliver new insights into the current understanding on the evolutionary effects of stock market liberalization and ensuing market integration in emerging market countries on the interdependence of its stock and bond market returns. In doing so, we contribute another facet of the financial impacts of emerging market integration with world capital markets. We also contribute to the measurement of stock-bond return comovement by adopting a non-parametric based concordance measure which is better suited to emerging market returns than standard parametric frameworks.

Given the substantial growth in funds invested in emerging market securities, further investigation into the stock-bond relationship in emerging markets is needed, perhaps at the firm-level. Future work could also focus on the channel of investor risk-aversion or sentiments in driving emerging stock-bond comovements.

\section{Appendix A. Relationship between the concordance measure and Pearson's correlation coefficient $\rho$}

Let $X_{t}, Y_{t}$ be time $t$ independent identically distributed realizations of random stationary processes $(X, Y)$ distributed according to the bivariate Normal distribution with means $\mu_{x}, \mu_{y}$, variances $\sigma_{x}^{2}, \sigma_{y}^{2}$ and correlation coefficient $\rho$, with density given by

$$
\begin{gathered}
f(x, y)=\frac{1}{2 \pi \sigma_{x} \sigma_{y} \sqrt{1-\rho^{2}}} \exp \left(-\frac{1}{2\left(1-\rho^{2}\right)}\left[\left(\frac{x-\mu_{x}}{\sigma_{x}}\right)^{2}\right.\right. \\
\left.\left.+\left(\frac{y-\mu_{y}}{\sigma_{y}}\right)^{2}-2 \rho \frac{\left(x-\mu_{x}\right)\left(y-\mu_{y}\right)}{\sigma_{x} \sigma_{y}}\right]\right) .
\end{gathered}
$$

Define concordance $C_{t}=\square\left(\left(X_{t}-\mu_{x}\right)\left(Y_{t}-\mu_{y}\right)\right)$ where as $\llbracket(z)$ is the indicator function, $\square(z)=1$ if $z \geqslant 0$ and $\square(z)=0$, otherwise.

The unconditional probability of concordant movement is then given by $E\left(C_{t}\right)$. Expanding the expectation operator we find

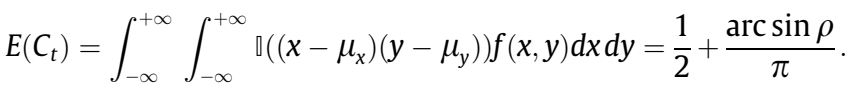

The inverse relationship is then $\rho=\sin \left(\pi\left(E\left(C_{t}\right)-\frac{1}{2}\right)\right)$.

\section{References}

Bae, K.-H., Chan, K., Ng, A., 2004. Investibility and return volatility. Journal of Financial Economics 71, 239-263.

Bae, K.-H., Bailey, W., Mao, C.X., 2006. Stock market liberalization and the information environment. Journal of International Money and Finance 25, $349-550$.

Bekaert, G., Harvey, C.R., 1995. Time-varying world market integration. Journal of Finance 50, 403-444.

Bekaert, G., Harvey, C.R., 1997. Emerging equity market volatility. Journal of Financial Economics 43, 29-77.

Bekaert, G., Harvey, C.R., 2000. Foreign speculators and emerging equity markets. Journal of Finance 55, 565-614.

Bekaert, G., Harvey, C.R., Lundblad, C., 2005. Does financial liberalization spur growth? Journal of Financial Economics 77, 3-55.

Boyer, B., Kumagai, T., Yuan, K., 2006. How do crises spread? Evidence from accessible and inaccessible stock indices. Journal of Finance 61, 957-1003.

Campbell, J.Y., Ammer, J., 1993. What moves the stock and bond markets? A variance decomposition for long-term asset returns. Journal of Finance 48, 3 37.

Cappiello, L., Engle, R.F., Sheppard, K., 2006. Asymmetric dynamics in the correlations of global equity and bond returns. Journal of Financial Econometrics 4, 537-572.

Carrieri, F., Errunza, V., Hogan, K., 2007. Characterizing world market integration through time. Journal of Financial and Quantitative Analysis 42, 915-940.

Chari, A., Henry, P.B., 2004. Risk sharing and asset prices: evidence from a natural experiment. Journal of Finance 59, 1295-1324

Chinn, M.D., Ito, H., 2006. What matters for financial development? Capital controls, institutions, and interactions. Journal of Development Economics 81, 163-192.

Chordia, T., Sarkar, A., Subrahmanyam, A., 2005. An empirical analysis of stock and bond market liquidity. Review of Financial Studies 18, 85-130.

Connolly, R., Stivers, C., Sun, L., 2005. Stock market uncertainty and the stock-bond return relation. Journal of Financial and Quantitative Analysis 40, 161-194.

De Jong, F., De Roon, F.A., 2005. Time-varying market integration and expected returns in emerging markets. Journal of Financial Economics 78, 583-613.

De La Torre, A., Gozzi, J.C., Schmukler, S.L., 2007. Stock market development under globalization: whither the gains from reforms? Journal of Banking and Finance 31, 1731-1754.

Edison, H.J., Warnock, F.E., 2003. A simple measure of the intensity of capital controls. Journal of Empirical Finance 10, 81-103.

Embrechts, P., McNeil, A., Straumann, D., 1999. Correlation: pitfalls and alternatives. Risk 12, 69-71. 
Erb, C., Harvey, C., Viskanta, T., 1999. A new perspective on emerging market bonds. Journal of Portfolio Management 25, 83-92.

Ferreira, M.A., Gama, P.M., 2007. Does sovereign debt ratings news spill over to international stock markets? Journal of Banking and Finance 31, 3162-3182.

Fleming, J., Kirby, C., Ostdiek, B., 1998. Information and volume linkages in the stock, bond and money markets. Journal of Financial Economics 49, 111137.

Henry, P.B., 2000a. Stock market liberalization, economic reform and emerging market equity prices. Journal of Finance 55, 529-564.

Henry, P.B., 2000b. Do stock market liberalizations cause investment booms? Journal of Financial Economics 58, 301-334

Kelly, J.M., Martins, L.F., Carlson, J.H., 1998. The relationship between bonds and stocks in emerging countries. Journal of Portfolio Management 24, 110-122.

Kendall, M., 1938. A new measure of rank correlation. Biometrika 30, 81-89.
Kim, S.-J, Moshirian, F., Wu, E., 2006. Evolution of international stock and bond market integration: influence of the European Monetary Union. Journal of Banking and Finance 30, 1507-1534.

Kim, E.H., Singal, V., 2000. Stock market openings: experiences of emerging economies. Journal of Business 73, 25-66.

Li, X.-M., Zou, L.-P., 2008. How do policy and information shocks impact comovements of China's T-bond and stock markets? Journal of Banking and Finance 32, 347-359.

Patro, D.K., Wald, J.K., 2005. Firm characteristics and the impact of emerging market liberalizations. Journal of Banking and Finance 29, 1671-1695.

Scruggs, J.T., Glabadanidis, P., 2003. Risk premia and the dynamic covariance between stock and bond returns. Journal of Financial and Quantitative Analysis $38,295-316$

Spearman, C., 1904. The proof and measurement of association between two things. American Journal of Psychology 15, 72-101. 